\title{
Efek Anti Histamin Ekstrak Daun Jambu Biji Pada Tikus Putih yang Dinduksi Ovalbumin Dinilai dari Jumlah Eosinofil Jaringan Kulit
}

\author{
Rendra Ristian Wibowo ${ }^{1}$, Ratih Dewi Yudhani² ${ }^{2}$ Novan Adi Setyawan ${ }^{3}$ \\ 1. Fakultas Kedokteran, Universitas Sebelas Maret \\ 2. Bagian Farmakologi, Fakultas Kedokteran, Universitas Sebelas Maret \\ 3. Bagian Patologi Anatomi, Fakultas Kedokteran, Universitas Sebelas Maret
}

Korespondensi : rendraristianw@student.uns.ac.id

\begin{abstract}
ABSTRAK
Pendahuluan: Prevalensi dan keparahan penyakit alergi terus meningkat secara global, terutama di negara dengan pendapatan rendah sampai menengah. Terapi alergi saat ini seperti kortikosteroid banyak memberikan efek samping dalam penggunaan jangka panjang. Ekstrak daun jambu biji (Psidium guajava) berpotensi sebagai antihistamin yang dapat menjadi terapi alternatif penyakit alergi. Penelitian ini bertujuan untuk mengetahui efek antihistamin ekstrak daun jambu biji (Psidium guajava) pada tikus putih (Rattus novergicus) yang diinduksi ovalbumin dinilai dari jumlah eosinofil jaringan kulit.

Metode: Penelitian ini merupakan penelitian quasi experimental design dengan rancangan post test only with control group design. Subjek penelitian tikus putih jantan, umur 3-4 bulan, dan berat badan 200-300 gram. Sampel 24 ekor tikus putih dibagi secara random menjadi enam kelompok. Kelompok kontrol normal (K) tanpa perlakuan, kontrol negatif (KN) hanya diinduksi ovalbumin, kontrol positif (KP) diberikan metilprednisolon, dan kelompok perlakuan (KP1, KP2, KP3) diberikan ekstrak daun jambu biji dengan dosis berikut $27 \mathrm{mg} / 200$ gramBB, $54 \mathrm{mg} / 200$ gramBB, dan $108 \mathrm{mg} / 200$ gramBB. Efek antihistamin dinilai melalui gambaran histopatologi jaringan kulit berupa rata-rata jumlah infiltrasi eosinofil dengan menggunakan mikroskop cahaya. Data dianalisis menggunakan uji Kruskal Wallis dan dilanjutkan uji Post Hoc Mann Whitney $(\alpha=0,05)$.

Hasil: Uji Kruskal Wallis menunjukkan perbedaan signifikan di antara enam kelompok perlakuan $(\mathrm{p}=0,00)$. Uji Post Hoc Mann Whitney menunjukkan perbedaan signifikan di antara semua pasangan kelompok $(\mathrm{p}=<0,05)$. KP3 menunjukkan rerata jumlah eosinofil lebih rendah daripada KP dan signifikan ( $\mathrm{p}=0,021)$.

Kesimpulan: Ekstrak daun jambu biji (Psidium guajava) memiliki efek antihistamin dengan menurunkan infiltrasi eosinofil pada jaringan kulit tikus putih (Rattus norvegicus) yang dinduksi ovalbumin.
\end{abstract}

Kata Kunci: ekstrak daun jambu biji; eosinophil; histopatologi kulit

\begin{abstract}
Introduction: The prevalence and severity of allergic diseases continues to increase globally, especially in countries with low to middle income. Current allergic therapies such as corticosteroids have many side effects in long-term use. Guava leaf extract (Psidium guajava) has the potential as an antihistamine which can be an alternative therapy for allergic diseases. This study aims to determine the effect of antihistamine extract of guava leaves (Psidium guajava) on white rats (Rattus novergicus) induced by ovalbumin assessed from the number of eosinophils of skin tissue.
\end{abstract}




\begin{abstract}
Methods: This research was a quasi experimental design with a post test only design with control group design. The research subjects were male white rats, aged 3-4 months, and weighing 200-300 grams. Samples of 24 white rats were randomly divided into six groups. Normal $(K)$ control group without treatment, negative control $(K N)$ was only induced by ovalbumin, positive control (KP) was given methylprednisolone, and treatment groups (KP1, KP2, KP3) were given guava leaf extract with the following dosage $27 \mathrm{mg} / 200$ gram BW, $54 \mathrm{mg} / 200$ gram BW, and $108 \mathrm{mg} / 200$ gram BW. The effect of antihistamines was assessed through histopathology of skin tissue in the form of an average number of eosinophil infiltrations using a light microscope. Data were analyzed using the Kruskal Wallis test and followed by the Mann Whitney Post Hoc test $(\alpha=0.05)$.

Result: The Kruskal Wallis test showed significant differences between the six treatment groups $(p=0.00)$. The Mann Whitney Post Hoc test showed significant differences between all group pairs $(p=<0.05)$. KP3 shows the average number of eosinophils lower than KP and significant $(p=0.021)$.

Conclusion: Guava leaf extract (Psidium guajava) has an antihistamine effect by reducing eosinophil infiltration in ovalbumin-induced white rat (Rattus norvegicus) skin tissue.
\end{abstract}

\title{
Keywords: Guava leaf extract; eosinophil; skin histopathology
}

\section{PENDAHULUAN}

Prevalensi dan keparahan penyakit alergi terus meningkat secara global, terutama di negara dengan pendapatan rendah sampai menengah ${ }^{1}$. Penggunaan terapi alergi jangka panjang selain dapat menyebabkan efek samping berupa sindroma Cushing juga membebani penderita dari segi ekonomi ${ }^{2}$. Daun jambu biji (Psidium guajava) secara tradisional digunakan untuk mengobati inflamasi, diabetes, hipertensi, luka, nyeri, dan demam $^{3}$. Ekstrak daun jambu biji kaya akan flavonoid, terutama turunan quercetin ${ }^{4}$. Quercetin mampu menekan aktivasi sel mast atau memiliki efek mast cell stabilizer ${ }^{5}$. Quercetin dalam daun jambu biji (Psidium guajava) berpotensi sebagai antihistamin yang dapat menjadi terapi alternatif pada penyakit alergi melalui mekanisme mast cell stabilizer dan penurunan jumlah sitokin yang berperan dalam reaksi alergi ${ }^{5}$. Penelitian ini bertujuan untuk mengetahui efek antihistamin ekstrak daun jambu biji (Psidium guajava) pada tikus putih (Rattus novergicus) yang diinduksi ovalbumin dinilai dari jumlah eosinofil jaringan kulit.

\section{METODE}

Penelitian ini menggunakan jenis penelitian quasi eksperimental dengan desain post test only with control group. Penelitian dilakukan di Laboratorium Farmakologi dan Laboratorium Patologi Anatomi, Fakultas Kedokteran, Universitas Sebelas Maret.

Hewan uji menggunakan Rattus
novergicus yang
Laboratorium Histologi, Fakultas Kedokteran, Universitas Sebelas Maret, Tikus putih (Rattus norvegicus) jantan, berumur 3-4 bulan, berat badan 200-300 gram, tidak ada kelainan anatomi. Sampel akan dianggap drop out apabila tikus putih mati, tidak bergerak aktif atau sakit saat dilakukannya penelitian.

Tikus putih dibagi menjadi 6 kelompok dengan masing-masing kelompok terdiri dari 4 ekor tikus putih secara random sampling. Pengelompokan tikus putih terdiri dari kelompok kontrol normal (K) tanpa perlakuan, kontrol negatif $(\mathrm{KN})$ hanya diinduksi ovalbumin, kontrol positif (KP) diberikan metilprednisolon, dan kelompok perlakuan (KP1, KP2, KP3) diberikan ekstrak daun jambu biji dengan dosis berikut 27 $\mathrm{mg} / 200$ gramBB, $54 \mathrm{mg} / 200$ gramBB, dan $108 \mathrm{mg} / 200$ gramBB. Adaptasi dilakukan selama tujuh hari (hari ke-1 sampai hari ke-7). 
Tikus kelompok perlakuan 1, 2, dan 3 diberikan ekstrak peroral setiap hari dari hari ke-8 sampai dengan hari ke-13 dengan dosis masing-masing. Tikus putih kelompok kontrol positif, kontrol negatif, dan perlakuan pada hari ke-8, ke-10, dan ke-12 disensitasi dengan injeksi suspensi ovalbumin $0,1 \%$ dalam $\mathrm{Al}(\mathrm{OH}) 310 \%$ dengan volume pemberian 1 $\mathrm{mL} / 200$ gramBB secara subkutan di punggung tikus.

Pada hari ke-14 dilakukan perlakuan, sebagai berikut:

a. K tidak diberikan perlakuan.

b. KN diinjeksikan dengan ovalbumin $0,1 \%$ dalam $\mathrm{Al}(\mathrm{OH}) 3 \quad 10 \%$ dengan volume pemberian $1 \mathrm{~mL} / 200$ gramBB secara subkutan di punggung tikus.

c. KP diberikan metilprednisolon sebesar $0,072 \mathrm{mg} / 200$ gram BB secara peroral dengan dilarutkan dalam $2 \mathrm{~mL}$ air.

d. KP1, KP2, dan KP3 diberikan ekstrak daun jambu biji secara peroral dengan dosis masing-masing $27 \mathrm{mg} / 200$ gram $\mathrm{BB}, 54$ $\mathrm{mg} / 200$ gram $\mathrm{BB}$, dan $108 \mathrm{mg} / 200$ gram BB yang dilarutkan dalam $2 \mathrm{~mL}$ air.

Setelah 30 menit, tikus diinjeksikan dengan suspensi ovalbumin $0,1 \%$ dalam $\mathrm{Al}(\mathrm{OH}) 310 \%$ dengan volume pemberian 1 $\mathrm{mL} / 200$ gramBB secara subkutan di punggung tikus. Jaringan kulit diambil 4 jam setelah injeksi, dan segera diproses guna membuat preparat histopatologi dengan pewarnaan HE. Semua data yang diperoleh akan ditabulasi, dibuat skoring jumlah eosinofil per lapang pandang pada perbesaran $400 \mathrm{X}$ dan dianalisis.

Uji normalitas dilakukan menggunakan uji Shapiro-Wilk, uji homogenitas menggunakan uji Levene. Analisis data menggunakan uji non parametrik yaitu uji Kruskal-Wallis dan uji Post Hoc Mann-Whitney karena syarat dilakukannya uji One Way ANOVA tidak terpenuhi. Kelaikan etik didapatkan dari KEPK Universitas Sebelas Maret Surakarta.

\section{HASIL}

\section{Data Hasil Penelitian}

Tabel 1. Rerata jumlah eosinofil pada setiap kelompok

\begin{tabular}{cc}
\hline Kelompok & Rerata Jumlah Eosinofil \\
\hline K & $1,45 \pm 0,23$ \\
KN & $15,95 \pm 0,83$ \\
KP & $2,90 \pm 0,21$ \\
KP1 & $7,30 \pm 0,14$ \\
KP2 & $4,25 \pm 0,17$ \\
KP3 & $2,20 \pm 0,35$
\end{tabular}

Keterangan:

$\mathrm{K}$ : kelompok kontrol normal; KN: kelompok kontrol negatif; KP: kelompok kontrol positif; KP1: kelompok perlakuan 1; KP2: kelompok perlakuan 2; KP3: kelompok perlakuan 3.

Pada kelompok $\mathrm{K}$ didapatkan rerata

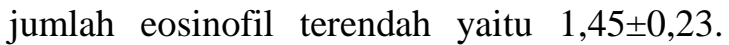
Kelompok KN menunjukkan rerata jumlah eosinofil tertinggi yaitu $15,95 \pm 0,83$. Rerata kelompok KP1 $(7,3 \pm 0,14), \operatorname{KP} 2(4,25 \pm 0,17)$, dan KP3 $(2,2 \pm 0,35)$ lebih rendah daripada kelompok KN $(15,95 \pm 0,83)$. Rerata jumlah eosinofil jaringan kulit terlihat semakin menurun dari kelompok KP1 hingga KP3, berturut-turut $7,3 \pm 0,14 ; \quad 4,25 \pm 0,17 ;$ dan $2,2 \pm 0,35$. KP3 $(2,2 \pm 0,35)$ menunjukkan rerata jumlah eosinofil yang lebih rendah daripada KP $(2,9 \pm 0,21)$.

\section{Analisis Data}

Uji Shapiro-Wilk menunjukkan bahwa data kelompok K, KN, KP, KP1, KP2, dan KP3 memiliki nilai $\mathrm{p}$ di atas derajat kemaknaan yang telah ditentukan $(p>0,05)$, sehingga data semua kelompok terdistribusi normal. Uji homogenitas menggunakan uji Levene didapatkan nilai $\mathrm{p}$ di bawah derajat kemaknaan yang telah ditentukan $(\mathrm{p}<0.05)$, sehingga data tidak homogen. Selanjutnya dilakukan uji alternatif untuk semua kelompok karena data tidak memenuhi syarat uji ANOVA yaitu data terdistribusi normal dan homogen. Uji alternatif yang digunakan adalah uji non parametrik Kruskal Wallis. 
Hasil uji Kruskal-Wallis menunjukkan nilai signifikansi $\mathrm{p}=<0,05$ $(\mathrm{p}<\alpha)$. Hasil tersebut menunjukkan bahwa terdapat perbedaan yang signifikan secara statistik antara enam kelompok perlakuan. Selanjutnya untuk mengetahui kelompok mana yang memiliki perbedaan yang signifikan dilakukan uji Post Hoc menggunakan Mann Whitney. Hasil uji Post Hoc Mann Whitney menunjukkan perbedaan yang signifikan $(\mathrm{p}=<0,05)$ di antara semua kelompok tikus.

\section{PEMBAHASAN}

Rerata jumlah eosinofil kelompok kontrol negatif $(15,95 \pm 0,83)$ lebih besar secara signifikan dibandingkan dengan kelompok kontrol normal $(1,45 \pm 0,23) \quad(\mathrm{p}=$ $0,020)$. Hasil tersebut menunjukkan bahwa pembuatan sampel model alergi menggunakan induksi ovalbumin dapat meningkatkan jumlah infiltrasi eosinofil jaringan kulit tikus putih. Ovalbumin mampu meningkatkan aktivitas limfosit Th2 dalam memproduksi IL4, IL-5 dan IL-13. IL-4, IL-13, dan IL-5 secara bersama-sama berperan dalam produksi IgE oleh sel B plasma dan rekrutmen serta aktivasi eosinofil ${ }^{6}$. Pemberian suspensi $\mathrm{Al}(\mathrm{OH})_{3}$ sebagai adjuvan dalam penelitian ini bertujuan untuk lebih menginduksi respon imun jalur Th2 yang berperan penting dalam reaksi alergi ${ }^{7}$. Proses inflamasi pada jaringan yang terjadi akibat reaksi sel mast menyebabkan pelepasan berbagai chemoattractant seperti CCL5, CCL11, CCL24, dan $\mathrm{CCL}_{2}{ }^{8}$. Melalui beberapa rangkaian proses tersebut, ovalbumin mampu meningkatkan jumlah infiltrasi eosinofil pada jaringan sesuai dengan hasil yang didapatkan dari penelitian ini.

Gambaran histopatologi pada semua kelompok perlakuan (kelompok perlakuan 1:

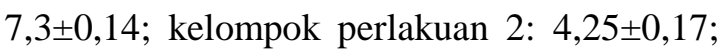
kelompok perlakuan 3: 2,2 $\pm 0,35$ ) menunjukkan rerata jumlah eosinofil yang lebih kecil bila dibandingkan dengan kelompok kontrol negatif $(15,95 \pm 0,83)$. Hasil tersebut menunjukkan bahwa pemberian ekstrak daun jambu biji (Psidium guajava) mampu menurunkan jumlah infiltrasi eosinofil jaringan kulit tikus putih. Uji statistik yang dilakukan pada kelompok kontrol negatif dan kelompok perlakuan 1, 2, dan 3 berturut-turut menunjukkan perbedaan yang signifikan $(p=0,020 ; \quad p=0,020 ; \quad p=0,021)$. Hasil pengamatan tersebut sesuai dengan penelitian Park et al (2009) bahwa quercetin mampu menurunkan jumlah infiltrasi eosinofil. Park et al (2009) dalam penelitiannya menggunakan tikus model asma yang diberikan quercetin murni, quercetin mampu menurunkan reaksi inflamasi saluran napas akibat alergi dan hiperresponsitivitas saluran napas melalui perubahan polarisasi Th1/Th2 via supresi ekspresi GATA-3 dan peningkatan ekspresi T-bet. GATA-3 merupakan gen yang meningkat ekspresinya saat sel $\mathrm{T}$ berdiferensiasi menjadi sel Th2 dan menurun saat sel $\mathrm{T}$ berdiferensiasi menjadi sel Th1, sedangkan T-bet merupakan faktor transkripsi yang menjadi penentu utama diferensiasi Th1 ${ }^{9}$. Melalui mekanisme tersebut, quercetin mampu menekan jumlah sel Th2 yang berperan penting dalam aktivasi dan rekrutmen eosinofil. Selain itu, quercetin berperan dalam menurunkan jumlah infiltrasi eosinofil pada jaringan melalui penekanan aktivasi sel mast (mast cell stabilizer) ${ }^{5}$. Hasil penelitian Kim et al (2014) menunjukkan quercetin secara signifikan mampu menekan ekspresi TNF- $\alpha$ dan IL-4 yang memiliki peranan penting dalam memicu dan mempertahankan reaksi alergi sel mast ${ }^{10}$. Selain melalui penekanan sel mast, quercetin mampu menurunkan sekresi sitokin dan ekpresi mRNA yang berperan dalam produksi, maturasi, dan rekrutmen eosinofil ${ }^{5}$. Pemberian quercetin pada hewan coba model asma juga memperlihatkan penurunan IL-4, IL-5, eotaksin CCL11 yang merupakan sitokin yang berperan dalam perkembangan, maturasi, dan 
rekrutmen eosinofil menuju tempat inflamasi ${ }^{5,8,11}$. Sehingga berdasarkan mekanisme tersebut, quercetin mampu menurunkan jumlah infiltrasi eosinofil pada jaringan.

Perbandingan dosis dari kelompok perlakuan 1 (KP1), kelompok perlakuan 2 (KP2), dan kelompok perlakuan 3 (KP3) menunjukkan bahwa penambahan dosis ekstrak daun jambu biji (Psidium guajava) semakin menurunkan infiltrasi eosinofil jaringan kulit secara signifikan (KP1 dengan KP2: $\mathrm{p}=0,019$; KP1 dengan KP3: $\mathrm{p}=0,020$; KP2 dengan KP3: $p=0,020$ ). Hasil ini sesuai dengan penelitian Sato et al (2015) yang menunjukkan supresi reaksi alergi berkolerasi positif dengan konsentrasi quercetin ${ }^{12}$. Dalam penelitian Park et al (2009) juga menunjukkan korelasi positif antara dosis pemberian quercetin dengan jumlah infiltrasi eosinofil. Pemberian quercetin sebesar $8 \mathrm{mg}$ menurunkan jumlah eosinofil sebesar $68,79 \%$ dibanding kelompok kontrol dan pemberian quercetin dengan dosis yang lebih besar yaitu $16 \mathrm{mg}$ mampu menurunkan jumlah eosinofil lebih besar daripada dosis $8 \mathrm{mg}$ sebesar $73,35 \%$ dibanding kelompok kontrol ${ }^{9}$. Hasil tersebut menunjukkan bahwa penambahan dosis quercetin mampu memberikan hasil yang lebih baik dalam menurunkan jumlah infiltrasi eosinofil.

Gambaran histopatologi kelompok kontrol positif menunjukkan penurunan jumlah rerata eosinofil dibandingkan kelompok kontrol negatif, hal ini membuktikan bahwa pemberian metilprednisolon mampu menurunkan jumlah infiltrasi eosinofil pada jaringan kulit tikus. Metilprednisolon mampu menurunkan jumlah sel Th2 GATA-3 dan produksi sitokin Th2 seperti IL-4, IL-5, IL-6, dan IL-13 tetapi tidak berpengaruh besar terhadap sel Th1 Tbet ${ }^{13}$.Melalui mekanisme tersebut metilprednisolon mampu menurunkan rerata jumlah infiltrasi eosinofil pada jaringan kulit tikus putih. Dari ketiga kelompok perlakuan, hanya kelompok perlakuan 3 memiliki rerata jumlah eosinofil lebih rendah $(2,2 \pm 0,35)$ dibandingkan kelompok kontrol positif $(2,9 \pm 0,21)$ dan signifikan secara statistik $(\mathrm{p}=$ 0,021). Hasil ini menunjukkan bahwa quercetin dalam ekstrak daun jambu biji (Psidium guajava) mampu menurunkan jumlah infiltrasi eosinofil melalui jalur yang sama dengan metilprednisolon melalui perubahan polarisasi Th1/Th2 via supresi GATA-3 ${ }^{9,13}$. Hasil ini juga menunjukkan bahwa quercetin dalam ekstrak daun jambu biji memiliki efek yang lebih baik dalam menurunkan infiltrasi eosinofil jaringan kulit dengan pemberian dosis ekstrak daun jambu biji sebesar $108 \mathrm{mg} / 200$ gramBB.

\section{KESIMPULAN}

Berdasarkan hasil penelitian dan analisis data menggunakan uji statistik yang telah dilakukan, maka dapat diketahui bahwa pemberian ekstrak daun jambu biji (Psidium guajava) dapat memberikan efek antihistamin berupa penurunan yang signifikan terhadap rerata jumlah eosinofil jaringan kulit tikus putih. Adapun dosis ekstrak daun jambu biji sebesar $108 \mathrm{mg} / 200$ gramBB menunjukkan hasil yang lebih baik dalam menurunkan infiltrasi eosinofil jaringan kulit tikus putih dibandingkan penggunaan metiprednisolon.

\section{UCAPAN TERIMA KASIH}

Peneliti mengucapkan terimakasih kepada semua pihak yang telah terlibat dan membantu dalam penyelesaian penelitian ini, terutama kepada staff Laboratorium Farmakologi, Laboratorium Patologi Anatomi, dan Laboratorium Histologi, Fakultas Kedokteran, Universitas Sebelas Maret.

\section{DAFTAR PUSTAKA}

1. Pawankar R, Canonica RW, Holgate ST, Lockey RL, \& Blaiss M. World Allergy Organization (WAO) White Book on 
Allergy: update 2013. Milwaukee: World Allergy Organization; 2013.

2. Ye Q, He XO, \& D'Urzo A. A Review on the Safety and Efficacy of Inhaled Corticosteroids in the Management of Asthma. Pulmonary Therapy 2017;3(1);118.

3. Arya V, Thakur N, Kashyap CP. Preliminary phytochemical analysis of the extracts of Psidium leaves. Journal of Pharmacognosy and Phytochemistry 2012;1(1).

4. El Sohafy SM, Metwalli AM, Harraz FM, Omar AA. Quantification of flavonoids of Psidium guajava L. Preparations by Planar Chromatography (HPTLC). Phcog Mag 2009;5;61.

5. Sakai-Kashiwabara M, Asano K. Inhibitory action of quercetin on eosinophil activation in vitro. EvidenceBased Complementary and Alternative Medicine 2013.

6. Deo SS, Mistry KJ, Kakade AM, Niphadkar PV. Role played by Th2 type cytokines in IgE mediated allergy and asthma. Lung India : official organ of Indian Chest Society 2010;27(2);66-71.

7. Wang W, Singh M. Selection of adjuvants for enhanced vaccine potency. World Journal of Vaccines 2011;1(02);33.

8. Ramirez GA, Yacoub MR, Ripa $M$, Mannina D, Cariddi A, Saporiti N, Ciceri F, et al. Eosinophils from Physiology to Disease: A Comprehensive Review. BioMed research international 2018.

9. Park HJ, Lee CM, Jung ID, Lee JS, Jeong YI, Chang JH, Chun SH, et al. Quercetin regulates $\mathrm{Th} 1 / \mathrm{Th} 2$ balance in a murine model of asthma. International immunopharmacology 2009;9(3);261267.

10. Kim M, Lim SJ, Kang SW, Um BH, Nho $\mathrm{CW}$. Aceriphyllum rossii extract and its active compounds, quercetin and kaempferol inhibit IgE-mediated mast cell activation and passive cutaneous anaphylaxis. Journal of agricultural and food chemistry 2014;62(17);3750-3758.

11. Fortunato LR, Alves CDF, Teixeira MM, Rogerio AP. Quercetin: a flavonoid with the potential to treat asthma. Brazilian journal of pharmaceutical sciences 2012;48(4);589-599.

12. Sato A, Zhang T, Yonekura L, Tamura H. Antiallergic activities of eleven onions (Allium cepa) were attributed to quercetin 4'-glucoside using QuEChERS method and Pearson's correlation coefficient. Journal of Functional Foods 2015;14;581589.

13. Okano M. Mechanisms and clinical implications of glucocorticosteroids in the treatment of allergic rhinitis. Clinical and experimental immunology $2009 ; 158(2) ; 164-173$ 